Selcuk Journal of Agriculture and Food Sciences

http://sjafs.selcuk.edu.tr/sjafs/index

Research Article
SJAFS

(2019) 33 (1), 19-25

e-ISSN: $2458-8377$

DOI: $10.15316 /$ SJAFS.2019.151

\title{
Investigation of the Last Irrigation Timing for Grain Corn under Konya Basin Conditions
}

\author{
Çağlar YAŞAR ${ }^{2}$, Ramazan TOPAK ${ }^{1, *}$ \\ ${ }^{1}$ Selçuk University, Department of Irrigation, Faculty of Agriculture, Konya, Turkey \\ ${ }^{2}$ Aksaray Agriculture Credit Cooperative, Aksaray, Turkey
}

\begin{tabular}{l}
\hline ARTICLE INFO \\
\hline Article history: \\
Received date: 05.03 .2019 \\
Accepted date: 19.03 .2019 \\
\hline Edited by: \\
Duran YAVUZ; Selçuk University, \\
Turkey \\
Reviewed by: \\
Ali ÜNLÜKARA; Erciyes Universiy, \\
Turkey \\
Yusuf UÇAR; Isparta University of \\
Applied Sciences, Turkey \\
\hline Keywords: \\
Maize \\
Termination time of irrigation \\
Grain yield \\
Gross income \\
\hline
\end{tabular}

\section{Introduction}

Among the cereals, maize is the third crop over the agricultural fields of Turkey after wheat and barley. It is grown either as the main crop or as the second crop. There is a distinctive increase in maize production of Turkey after 1980s. According to TÜİK (2018) data, in 2017, grain corn production was practiced over 640.000 ha land areas in Turkey and about 5.9 million tons of kernel was produced. Konya basin has a significant place in maize production of Turkey. Again according to TÜİK (2018) data, in 2013, grain corn production was practiced over 49.000 ha land area of Konya basin (including Konya, Karaman, Aksaray, Niğde provinces) and about 497.000 tons of kernel was produced. In 2017, 950.000 tons of kernel was produced from 100.000 ha maize fields of especially Konya (64.000 ha), Karaman (28.000 ha) and Aksaray (7.000 ha) provinces. Of this quantity of total production, 620.000 tons were produced in Konya province. All these data indicate that about $16 \%$ of total maize production of Turkey came from Konya basin. Konya province alone constitute about $11 \%$ of grain corn production of Turkey.

\footnotetext{
*Corresponding author email: rtopak@selcuk.edu.tr
}

Konya basin is the least precipitated region of Turkey and has a semi-arid climate. The basin has about $12 \%$ of arable lands of Turkey, but has only $3 \%$ of available water resources. Such a number indicate quite limited nature of water resources in the basin. For a successful and sustainable agricultural production in Konya basin and similar fields, irrigation is essential. Besides, it is quite hard to achieve sustainable water resources use in such areas. Together with current global warming and environmental pollution, solutions are sought to reduce agricultural water use in several parts of the world. In this sense, current researches mostly focus on development of drought-resistant plant cultivars and water-saving irrigation technologies.

Maize kernels should have a moisture content of around $14-15 \%$ before to store them. Kernels have a moisture content of $30-35 \%$ in the field when they reached to physical maturity stage. Such moisture levels are not appropriate for machine-harvest of the plants because of high yield losses. Even they harvested at these moisture levels, kernels should be dried before storage as to reduce the kernel moisture levels to 14-15\%. Drying brings about an extra cost and thus reduces grower incomes. In sweet corns, kernel moisture level should be around $20 \%$ for machine-harvest of the plants. Irrigation constitutes an essential compo- 
nent of maize culture under Konya provincial conditions. However, irrigations beyond a point do not have significant effects on yields. Such irrigations even slow down decreases in kernel moisture levels, thus delay potential harvest times until winter months. Since the fields are wet and muddy in winter months, machineharvest will not be possible, then growers have to manually harvest their fields. Manual harvests then increase the costs of production. The most appropriate way to overcome such problems is to terminate irrigations early. Early termination of irrigations in maize culture requires well-comprehension of water-yield relations. There is a limited information about early termination of irrigations in maize culture. Previous researches on early-termination of irrigations revealed that termination of irrigations at dough and physiological maturity stages did not have significant effects on yields of popcorn (Thanomsub et al., 2001; Sweeney and Marr, 2005; Yerdoğan and Gözübenli, 2015) and grain corn (Şahin, 2015). There aren't any researches conducted about early-termination of irrigation in maize culture of Konya basin. Therefore, the present study was conducted to determine the timing of the last irrigation in

Table 1

Climate parameters for Kazımkarabekir town (Anonymous, 2018).

\begin{tabular}{|c|c|c|c|c|c|c|c|c|c|c|c|c|c|}
\hline \multirow{2}{*}{ Year } & \multirow{2}{*}{$\begin{array}{l}\text { Meteorological } \\
\text { Data }\end{array}$} & \multicolumn{12}{|c|}{ Months } \\
\hline & & 1 & 2 & 3 & 4 & 5 & 6 & 7 & 8 & 9 & 10 & 11 & 12 \\
\hline \multirow{4}{*}{$\stackrel{\infty}{\stackrel{0}{\sigma}}$} & Nisbi nem (\%) & 84.2 & 69.6 & 56.9 & 49.8 & 58.6 & 51.9 & 39.3 & 35.9 & 39.5 & - & - & - \\
\hline & Temperature $\left({ }^{\circ} \mathrm{C}\right)$ & 1.5 & 6.6 & 10.6 & 13.5 & 17.3 & 21 & 24.8 & 24.4 & 20.3 & - & - & - \\
\hline & Precipitation (mm) & 59.6 & 15.5 & 42.3 & 13.2 & 33.4 & 68.4 & 8.5 & 8 & 7.9 & - & - & - \\
\hline & Wind Speed $\left(\mathrm{ms}^{-1}\right)$ & 3.8 & 3.4 & 4.2 & 3.1 & 2.7 & 2.9 & 3.9 & 3.6 & 3 & - & - & - \\
\hline \multirow{4}{*}{ 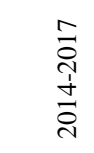 } & R. Humidity (\%) & 81.7 & 73 & 64 & 53.3 & 55.5 & 53.9 & 36.7 & 41 & 42.9 & 56.4 & 65.2 & 80.5 \\
\hline & Temperature $\left({ }^{\circ} \mathrm{C}\right)$ & -0.4 & 3.1 & 7.3 & 12 & 16.2 & 20.3 & 24.7 & 24.9 & 20.5 & 13.9 & 6.9 & 2 \\
\hline & Precipitation (mm) & 51.6 & 24.8 & 48.5 & 25.4 & 40.6 & 58.8 & 6.5 & 13.4 & 20.6 & 49.1 & 36.7 & 43.5 \\
\hline & Wind Speed $\left(\mathrm{ms}^{-1}\right)$ & 3.9 & 3.4 & 3.8 & 3.4 & 3.3 & 3.1 & 3.7 & 3.3 & 2.7 & 2.9 & 2.6 & 3 \\
\hline
\end{tabular}

Table 2

Irrigation-related soil characteristics of the experimental plots.

\begin{tabular}{lccccccc}
\hline $\begin{array}{l}\text { Soil layer } \\
(\mathrm{cm})\end{array}$ & $\begin{array}{c}\text { Clay } \\
(\%)\end{array}$ & $\begin{array}{c}\text { Silt } \\
(\%)\end{array}$ & $\begin{array}{c}\text { Sand } \\
(\%)\end{array}$ & $\begin{array}{c}\text { Texture } \\
\text { Class }\end{array}$ & Field Capacity (\%) & Wilting Point $(\%)$ & $\begin{array}{c}\text { Bulk Density } \\
(\mathrm{g} \mathrm{cm})\end{array}$ \\
\hline $0-30$ & 36.1 & 26.25 & 37.65 & CL & 30.41 & 15.41 & 1.57 \\
$30-60$ & 40.2 & 18.75 & 41.05 & C & 33.67 & 14.34 & 1.52 \\
$60-90$ & 35.2 & 20.00 & 44.80 & CL & 33.54 & 14.23 & 1.37 \\
\hline
\end{tabular}

A deep well located within the experimental fields was used as irrigation water supply. Well discharge was about $85 \mathrm{~m}^{3} \mathrm{~h}^{-1}$. Seeds of 0573 Pioneer grain corn were sown. Dough stage was taken into consideration in experimental design, thus the first irrigation termination treatment was conducted at milk stage. There were 5 different irrigation termination dates in experimental

Table 3

Experimental treatments

\begin{tabular}{lc}
\hline Treatments & Explanation \\
\hline S1 & Last irrigation, at milk stage. \\
S2 & Last irrigation, 6 days after S1. \\
S3 & Last irrigation, 12 days after S1. \\
S4 & Last irrigation, 18 days after S1. \\
S5 & Last irrigation, 24 days after S1. \\
\hline
\end{tabular}

grain corn production for an economic production under Konya basin conditions.

\section{Materials and Methods}

This study was conducted over the maize fields of a farmer in Kazımkarabekir town of Karaman province. The town is located at $37^{\circ} 14^{\prime}$ North latitudes and $32^{\circ}$ $57^{\prime}$ east longitudes and has an altitude of $1030 \mathrm{~m}$ (Anonymous, 2015). Terrestrial climate is dominant in Central Anatolia region including Kazımkarabekir town. Summers are hot and dry and winters are cold and harsh. Climate data of Kazımkarabekir town were started to be measured from the year 2014 and measured climate parameters are provided in Table 1. As can be seen from the table presenting meteorological data of 2014-2017 period, annual average temperature is $12.6{ }^{\circ} \mathrm{C}$, average relative humidity is $58.7 \%$, average wind speed is $3,3 \mathrm{~m} / \mathrm{s}$ and annual total precipitation is $419.5 \mathrm{~mm}$. Present study was conducted throughout the initial 9 months of 2018 and total precipitation for that period of experiments was $256,8 \mathrm{~mm}$. Some irrigationrelated soil characteristics of the experimental fields are provided in Table 2. design. Experiments were conducted in randomized plots design with three replications. Present treatments and explanations of the treatments are provided in Table 3. There were 6 days between consecutive irrigation-termination dates and $20 \mathrm{~mm}$ irrigation water was applied at the last irrigation of each irrigationtermination treatment. 
The farmer divided experimental fields into 5 equal plots $(300 \times 72 \mathrm{~m}=21.6 \mathrm{da})$ based on available discharge of the water well and installed drip irrigation units accordingly. Within the scope of this study, a lateral line was closed in each operational unit at the time of irrigation termination and the other lines continued operation. In this way, 5 different irrigation termination times were generated. Irrigation area of the initial $100 \mathrm{~m}$ section of the lateral line closed in each drip irrigation unit constituted an experimental treatment. Then, this $100 \mathrm{~m}$ section was divided into three equal parts as to represent the replications of each treatment.

Before sowing, $32.8 \mathrm{~kg} \mathrm{da}^{-1}$ DAP fertilizer $(18 \%$ $\mathrm{N}-46 \% \mathrm{P}$ ) and $10 \mathrm{~kg} \mathrm{da}^{-1}$ Ammonium Sulphate fertilizer $(21 \% \mathrm{~N}-24 \% \mathrm{~S})$ were broadcasted to experimental fields with a fertilizer distributor machine as base fertilizer and then incorporated into the soil. Sowing was performed over 108 decare land area on 26 April 2018. Sowing was performed with a 6-row grain drill as to have $70 \mathrm{~cm}$ row spacing and $15.3 \mathrm{~cm}$ on-row plant spacing. A sprinkler irrigation was performed as to have homogeneous emergence. Drip irrigation system was installed over the experimental fields on $8-9^{\text {th }}$ of July. A lateral line (300 m long and Ø25 mm diameter) was installed for two plant rows $(140 \mathrm{~cm}$ lateral spacing). Drippers were $30 \mathrm{~cm}$ apart and had a discharge of 1.6 $\mathrm{Lh}^{-1}$. Following the installation, the first drip irrigation was performed. Dressing fertilizer was applied through irrigation lines (fertigation). With the initial two irrigations, a total of $8.5 \mathrm{~kg} \mathrm{da}^{-1}$ urea $(46 \% \mathrm{~N})$ was applied as dressing fertilizer. Also, $2.8 \mathrm{~kg} \mathrm{da}^{-1}$ Potassium Sulphate-powder and $2.8 \mathrm{~kg} \mathrm{da}^{-1}$ Mono Ammonium Phosphate (MAP)-powder fertilizers were applied to plants. During the period from sowing to initiation of the experiments, drip irrigation treatments were started on $9^{\text {th }}$ of June, irrigations were performed in 3 or 5 day intervals for 3-5 hours. Considering the initial irrigation-termination treatment, a total of $440 \mathrm{~mm}$ irrigation water was applied to the entire plot for 550 hours of drip irrigation from $85 \mathrm{~m}^{3} \mathrm{~h}^{-1}$ discharge deep well. Since the entire filed was divided into five equalsize plots $(21.6 \mathrm{da})$, each plot was irrigated for 110 hours. During the harvest, initial $100 \mathrm{~m}$ section of

Table 4

Total amount of irrigation water applied to treatments

\begin{tabular}{lccccc}
\hline & \multicolumn{4}{c}{ Treatments } \\
\cline { 2 - 6 } & S1 & S2 & S3 & S4 & S5 \\
\hline Sprinkler irriation (mm) & 48.6 & 48.6 & 48.6 & 48.6 & 48.6 \\
Drip irrigation (mm) & 440.5 & 460.5 & 480.5 & 500.5 & 520.5 \\
Total irrigation water (mm) & 489.1 & 509.1 & 529.1 & 549.1 & 569.1 \\
Rainfall (mm) & 126.2 & 126.2 & 126.2 & 126.2 & 126.2 \\
\hline
\end{tabular}

With the irrigation performed on the first irrigation termination date of 11.08.2018 (S1 treatment), all treatments had equivalent quantity of irrigation water. On 11.08.2018, S1 treatment was irrigated for the last time. By this date, all treatments received $489.1 \mathrm{~mm}$ (440.5 $\mathrm{mm}$ through drip lines and $48.6 \mathrm{~mm}$ through sprinklers) irrigation water. Within the scope of this closed lateral line was divided into three equal sections as to create replications. From the mid-sections of each plot, $5 \mathrm{~m}$ sections were considered as harvest plot and ears of this section were harvested. In other words, harvest plot had a size of $3.5 \mathrm{~m}^{2}(5 \times 0.7 \mathrm{~m})$. Kernel moisture contents were measured and harvest was performed manually. Harvested ears were placed into sacks. They were counted and number of ears per harvest plot of each treatment was determined. Ears were husked and kernels were trashed manually. Resultant kernels were weighed to get harvest plot kernel yields of each treatment. Then, these plot yields were converted into yield per decare. Treatment yields were corrected for $15 \%$ moisture content. Corrected yield per decare was then calculated as $($ CYD $)=$ Yield $(\mathrm{kg}$ $\left.\mathrm{da}^{-1}\right) \times(100-\%$ Moisture $) / 85$.

To determine yield components, ears harvested from randomly selected 5 plants of each plot were used. Husked ear weight, husked ear length, number of kernel rows, number of kernels per row, 100-kernel weight were determined and resultant values were corrected for $15 \%$ moisture content.

Resultant data were subjected to analysis of variance and significant means were compared with the aid of Duncan's multiple range test at 5\% level of significance. Statistical analyses were performed with the use of SPSS 22.0 statistical software.

\section{Results and Discussion}

\subsection{Irrigation treatments}

Amount of irrigation water applied in each treatment is provided in Table 4. A sprinkler irrigation was performed for homogeneous emergence throughout the field and a total of $48.6 \mathrm{~mm}$ water was applied through sprinklers. The initial drip irrigation was performed on tervals for about 3 or 5 hours until $11^{\text {th }}$ of August when the designed irrigation treatments were initiated. Total precipitation between sowing and harvest $\left(26^{\text {th }}\right.$ of April $-26^{\text {th }}$ of September) was $126.2 \mathrm{~mm}$. Of such an amount, $54.2 \%$ was received in June and $26.5 \%$ was received in May. $9^{\text {th }}$ of June. Irrigations were repeated at 3 or 5 day in-

study, $509.1 \mathrm{~mm}$ water was applied to $\mathrm{S} 2$ treatment, $529.1 \mathrm{~mm}$ to S3 treatment, $549.1 \mathrm{~mm}$ to S4 treatment, $569.1 \mathrm{~mm}$ to S5 treatment. Irrigations were terminated 107 days after sowing in S1 treatment, 113 days in S2, 119 days in S3, 125 days in S4 and 131 days in S5 treatment. As compared to S1 treatment, 20, 40, 60 and $80 \mathrm{~mm}$ more irrigation water was applied in S2, S3, S4 
and S5 treatments, respectively.

\subsection{Kernel yields}

Total growing season of sweet corn was about 150 days. Ear harvest was performed on $21^{\text {st }}$ of September

Table 5

Number of ears harvested from the harvest plots of each irrigation-termination treatments

\begin{tabular}{lcccc}
\hline Treatments & Replications & \multicolumn{3}{c}{$\begin{array}{c}\text { Average } \\
\text { (Number) }\end{array}$} \\
\hline S1 & 1 & 2 & 3 & 4 \\
S2 & 34 & 33 & 32 & 33 \\
S3 & 30 & 31 & 30 & 30 \\
S4 & 29 & 30 & 31 & 30 \\
S5 & 34 & 32 & 30 & 32 \\
\hline
\end{tabular}

As can be seen from the table, there were not significant differences in number of ears of both the treatments and treatment replicates. Such a case indicated a homogeneous nature of number of ears of the treatments. Kernel yields of the experimental treatments are provided in Table 6. Variance analysis revealed that different irrigation-termination dates did not have significant effects on kernel yields. The greatest kernel yield $\left(1422.8 \mathrm{~kg} \mathrm{da}^{-1}\right)$ was obtained from the last irrigation-termination date (S5 treatment) and the least kernel yield $\left(1141.8 \mathrm{~kg} \mathrm{da}^{-1}\right)$ was obtained from the first irrigation-termination date (S1 treatment). As compared to S5 treatment, respectively 14 and $10.5 \%$ water saving was achieved, but 20 and $15 \%$ yield decrease was observed in S1 and S2 treatments. In other

Table 6

Kernel yields of the experimental treatments (corrected for $15 \%$ moisture level)

\begin{tabular}{lcccc}
\hline Treatments & $\begin{array}{c}\text { Amount of irriga- } \\
\text { tion water }(\mathrm{mm})\end{array}$ & $\begin{array}{c}\text { Water saving } \\
(\%)\end{array}$ & $\begin{array}{c}\text { Grain yield } \\
\left(\mathrm{kg} \mathrm{da}^{-1}\right)\end{array}$ & $\begin{array}{c}\text { Relative graint } \\
\text { yield }(\%)\end{array}$ \\
\hline S1 & 489.1 & 14 & 1141.8 & 80.24 \\
S2 & 509.1 & 10.5 & 1235.4 & 86.82 \\
S3 & 529.1 & 7 & 1321.9 & 92.90 \\
S4 & 549.1 & 3.5 & 1382.4 & 97.15 \\
S5 & 569.1 & - & 1422.9 & 100 \\
\hline
\end{tabular}

\subsection{Yield components}

Measurements were made to assess the effects of experimental treatments on yield components (husked ear length, number of kernel rows, number of kernels per row and 100-kernel weight). Results for yield components are provided in Table 7 . While the experimental treatments had significant effects on husked ear lengths $(\mathrm{p}<0.05)$, effects of irrigation-termination treatments on the other yield components were not found to be significant.

According to data provided in Table 7, the shortest husked ear length $(12.76 \mathrm{~cm})$ was observed in the ear- words, the rate of decrease in yield was greater than the rate of water saving. Although the differences in yields of treatments were not significantly different, it can still be stated that early termination of irrigation ended up with a yield loss as compared to late termination dates. Former field experiments on applying different irrigation termination in some field crops, such as maize (Thanomsub et al., 2001; Alam et al., 2002; Sweeney and Marr, 2005; Şahin, 2015; Yerdoğan and Gözübenli, 2015), tomato (Marouelli et al., 2004), cotton (Buttar et al., 2007), cowpea (Daneshnia et al., 2013), have shown that early irrigation termination plays an important role in decreasing yield compared to late termination. liest irrigation-termination treatment (S1). Ear lengths of the other treatments varied between $14.86-15.83$ $\mathrm{cm}$ and the differences in ear lengths were not found to be significant. The 100-kernel weights of the treatments varied between 26.36 - $34.56 \mathrm{~g}$ with the lowest value in S1 treatment and the greatest value in S5 treatment. The lowest number of kernels per row (30.86 kernels) was obtained from the earliest irrigation termination date (S1) and the values of the other treatments varied between 34.4 - 35.53 kernels. Number of kernel rows (number of kernels around a vertical row) varied between 15.33-16. 
Table 7

Data on yield components

\begin{tabular}{lcccc}
\hline Treatments & 100-tseed weight $(\mathrm{gr})$ & Cob length $(\mathrm{cm})$ & $\begin{array}{c}\text { Number of grain per row } \\
\text { (Adet) }\end{array}$ & $\begin{array}{c}\text { Number of rows per cob } \\
\text { (Adet) }\end{array}$ \\
\hline S1 & 26.36 & $12.76 \mathrm{~b}$ & 30.86 & 15.33 \\
S2 & 31.30 & $15.63 \mathrm{a}$ & 35.53 & 16.00 \\
S3 & 28.20 & $14.86 \mathrm{a}$ & 34.40 & 15.33 \\
S4 & 28.76 & $15.00 \mathrm{a}$ & 34.40 & 15.73 \\
S5 & 34.56 & $15.83 \mathrm{a}$ & 34.73 & 15.73 \\
\hline
\end{tabular}

\subsection{Gross production values corrected for irrigation electricity costs}

The early irrigation-termination treatments (S1, S2 and S3) were harvested on $21^{\text {st }}$ of September and the other treatments were harvested a day before regular harvest date of the farmers on $26^{\text {th }}$ of September. On

Table 8

Sweet corn prices at the date of harvest in Konya region ( $\mathrm{TL} \mathrm{da}^{-1}$ ).

\begin{tabular}{|c|c|c|c|c|c|}
\hline Date of harvest & Agricultural Credit Cooperatives & Konya Commodity Exchange & Konya Sugar Co. & Others & Average \\
\hline 21.09 .2018 & 1.10 & 1.04 & - & 1.05 & 1.063 \\
\hline 26.09.2018 & 1.00 & 1.04 & 1.038 & 1.00 & 1.020 \\
\hline
\end{tabular}

Kernel yields of the treatments were multiplied by unit prices to get gross product per unit area. Resultant values are provided in Table 9.

Table 9

Unit-area production values of the experimental treatments $\left(\mathrm{TL} \mathrm{da}^{-1}\right)$

\begin{tabular}{lcccc}
\hline \multirow{2}{*}{ Treatments } & \multicolumn{3}{c}{ Replication } & \multirow{2}{*}{ Average } \\
\cline { 2 - 4 } & 1 & 2 & 3 & 1213.74 \\
S1 & 1073.02 & 1049.94 & 1518.27 & 1313.26 \\
S2 & 1595.11 & 1237.02 & 1107.65 & 1405.62 \\
S3 & 1422.44 & 1276.61 & 1517.83 & 1410.03 \\
S4 & 1380.78 & 1500.86 & 1348.44 & 1451.32 \\
S5 & 1481.34 & 1363.02 & 1509.60 & \\
\hline
\end{tabular}

Based on the early irrigation-termination treatment (S1), irrigation electricity costs were calculated for the other treatments (S2, S3, S4 and S5). Monthly electricity cost of the well (utility bill) was divided by monthly operational time of the well to get unit-time (h) electricity cost. Then, unit electricity costs $\left(24 \mathrm{TLh}^{-1}\right)$ was

Table 10

Electricity costs of the experimental treatments

\begin{tabular}{lcc}
\hline Treatments & Irrigation duration $\left(\mathrm{h} \mathrm{da}^{-1}\right)$ & Electricity cost for irrigation $\left(\mathrm{TL} \mathrm{da}^{-1}\right)$ \\
\hline S1 & 0 & 0 \\
S2 & 5 & 5.55 \\
S3 & 10 & 11.1 \\
S4 & 15 & 16.65 \\
S5 & 20 & 22.2 \\
\hline
\end{tabular}

Irrigation electricity costs were then subtracted from total production values of irrigation-termination divided by irrigation unit size (21.6 da) to get unit-time electricity cost per decare (1,11 TL). This value was multiplied by extra irrigation times to get the electricity costs of the other treatments. Resultant data are provided in Table 10. treatments to get adjusted unit-area production values. Resultant data are provided in Table 11. the date of harvest of the experimental treatments, sweet corn unit prices ( $\mathrm{TL} \mathrm{da}{ }^{-1}$ ) based on $15 \%$ kernel moisture content were taken from Turkish Agricultural Credit Cooperatives, Konya Commodity Exchange, Konya Sugar Co. and private sector (recorded as the others) and summarized in Table 8. 
Table 11

Adjusted gross products of the experimental treatments

\begin{tabular}{lccc}
\hline Treatments & $\begin{array}{c}\text { Gross income } \\
\left(\mathrm{TL} \mathrm{da}^{-1}\right)\end{array}$ & $\begin{array}{c}\text { Electricity cost for irri- } \\
\text { gation }^{(\mathrm{TL} \mathrm{da})^{-1}}\end{array}$ & $\begin{array}{c}\text { Adjusted gross income } \\
\left(\mathrm{TL} \mathrm{da}^{-1}\right)\end{array}$ \\
\hline S1 & 1213.74 & 0 & 1213.74 \\
S2 & 1313.26 & 5.55 & 1307.71 \\
S3 & 1405.62 & 11.1 & 1394.52 \\
S4 & 1410.03 & 16.65 & 1393.38 \\
S5 & 1451.32 & 22.2 & 1429.12 \\
\hline
\end{tabular}

Variance analysis revealed that different irrigationtermination dates did not have significant effects on adjusted gross product. As can be seen from the gross products provided in Table 11, the greatest value (1429 TL $\mathrm{da}^{-1}$ ) was obtained from the latest irrigationtermination date (S5 treatment) and the lowest value $\left(1231 \mathrm{TL} \mathrm{da}^{-1}\right)$ was obtained from the earliest irrigation-termination date ( $\mathrm{S} 1$ treatment). As compared to the latest irrigation-termination date (S5), adjusted gross product in S1 and S2 treatments was respectively 216 and $122 \mathrm{TLda}^{-1}$ less and reduction in S3 and S4 treatments was about $35 \mathrm{TL} \mathrm{da}^{-1}$. Although the differences in kernel yields and adjusted gross products of the treatments were not significant, it was observed that prolongation of irrigation-termination dates relatively increased both the kernel yields and adjusted gross products (Figure 1).

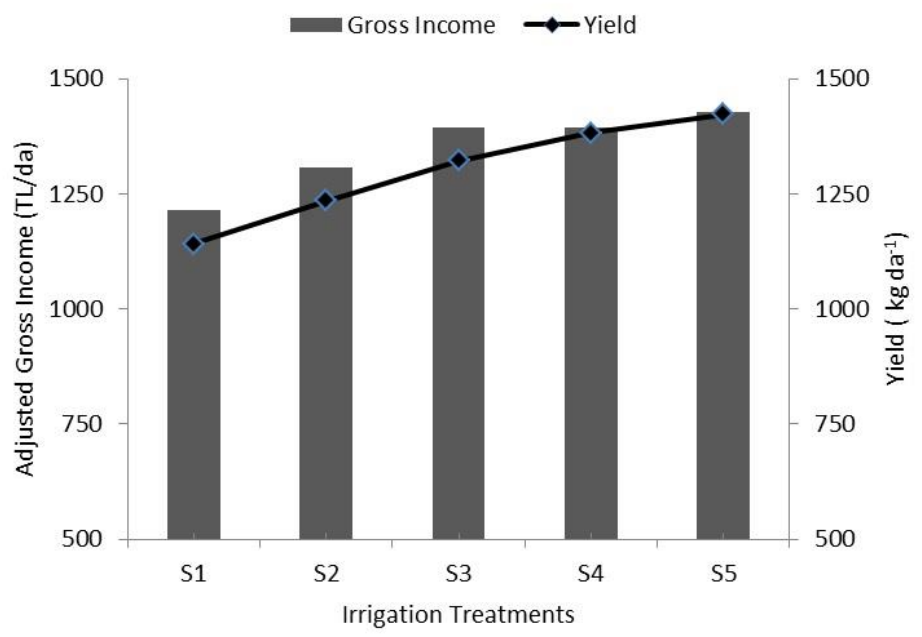

Figure 1

Effects of irrigation-termination dates on kernel yield and adjusted gross income

\section{Conclusion}

Present findings revealed that different irrigationtermination dates after milk stage did not have significant effects on kernel yields and adjusted gross products of grain corn. Besides, partial increases were observed in yield and gross products with the prolongation of irrigation-termination dates. As it was stated earlier, this study was conducted over the production fields of a farmer. Therefore, entire conditions of an irrigation-termination study were not able to be achieved. Thus, further research is recommended under more comprehensive and controlled conditions in Konya basin.

\section{Acknowledgements}

This manuscript was derived from Master's Thesis of Çağlar YAŞAR.

\section{References}

Alam M, Rogers DH, Dumler TJ, Gold GL (2002). Effect of 1rrigation ending date on corn yield and 1rrigation scheduling for water conservation. ASAE Annual International Meeting / CIGR $\mathrm{XV}^{\text {th }}$ World Congress, July 28-31, Chicago, Illinois, USA.

Anonymous (2015). Kazımkarabekir Kaymakamlığı, http://www.kazimkarabekir.gov.tr/cografi-durum.

Anonymous (2018). Karaman İli Kazımkarabekir İlçesi 2014-2018 İklim Verileri, https://www.mgm.gov.tr/site/bilgiedinme.aspx? $\mathrm{r}=\mathrm{d}$.

Buttar GS, Aujla MS, Thind HS, Singh CJ, Saini KS (2007). Effect of timing of first and last irrigation on the yield and water use efficiency in cotton. $A g$ ricultural Water Management, 89: 236-242.

Daneshnia R, Mojaddam M, Nejad TS (2013). Effect of irrigation-ending at reproductive stage and plant density on grain yield and yield components in 
cowpea. Scientific Journal of Agronomy and Plant Breeding, 1(2): 15-21.

Marouelli WA, Silva WLC, Moretti CL (2004). Production, quality and water use efficiency of processing tomato as affected by the final irrigation timing. Horticultura Brasileira, 22 (2): 226-231.

Sweeney DW, Marr, CW (2005). Supplemental irrigation at reproductive growth stages to improve popcorn grown at different populations. Agronomy Journal, 97 (3): 741-745.

Şahin MD (2015). Harran ovası koşullarında farklı ekim zamanlarının ve generatif dönemde farklı zamanlarda sulama sonlandırmanın misır verimine etkisi. Yüksek lisans tezi, Kahramanmaraş Sütçü
İmam Üniversitesi Fen Bilimleri Enstitüsü, Kahramanmaraş.

Thanomsub W, Kraokaw S, Promkum W, Phoomthaisong J (2001). Responses of popcorn to irrigation rate sandtiming of irrigation termination. Thai $\mathrm{Ag}$ ricultural research Journal, 19(2): 157-167.

TÜİK (2018). Bitkisel Üretim İstatistikleri, https://biruni.tuik.gov.tr/medas/?kn=92\&locale=tr:

Yerdoğan K, Gözübenli H (2015). Sulamayı sonlandirma zamanının cin misirı (Zea mays everta Sturt.)'nın Verim ve Verim Unsurları ile Bazı Kalite özelliklerine etkisinin belirlenmesi, 11. Tarla Bitkileri Kongresi Bildiri Özetleri Kitabı, 226-229, Cilt 1, 7-10 Eylül Çanakkale. 